\title{
Muslim Americans: Debating the Notions of American and Un-American
}

\author{
Nahid Kabir \\ New York: Routledge, 2016. 307 pages.
}

Muslim Americans: Debating the Notions of American and Un-American is an ambitious attempt to explore how American Muslims, especially immigrants and their children, see the US and are seen by it. It uses the voices of Muslim Americans to explore what peoples and cultures can be considered American, and which are not. The author offers it as "a counter-narrative to the reactionary thinking of academics ... and some media and politicians who have place Islam/Muslims as the Other."

The first chapter describes a background discourse in which Islam is assumed to be in conflict with America specifically, and the western world more generally. It also describes the multiple methodological tools that the book brings to bear in order to understand how Muslims see US society and their place in it. Finally, it lays out some of the limitations of the researchone of the most prominent of which is its focus on Muslims of South Asian or Middle Eastern decent and living in areas with relatively large numbers of Muslims, such as parts of New York, New Jersey, and Michigan.

Chapter 2 uses in-depth interviews with US Muslims to describe their views of what it means to be American or un-American. It finds that Muslims living in the US generally see Americanness in a positive light, and generally see themselves as American. In fact, some argued that anti-Muslim treatment and bigotry are themselves un-American. The chapter also highlighted considerable diversity, with Muslims disagreeing about whether positive American values were uniquely American and some highlighting racial components of American identity.

Chapter 3 highlights some of the tools that immigrants and their children deploy in attempting to navigate "Islamic" culture, "American" culture, and "ethnic" cultures on issues such as parenting, dating, and gender roles. It argues that those who have substantial literacy across multiple cultures (i.e. those who are "bicultural") can more effectively navigate norms across cultural contexts. Further, it suggests that bicultural parents are better equipped to aid their children.

Chapter 4 analyzes some media coverage of Islam and Muslims. It argues that this coverage is often (though not exclusively) itself un-American 
(or at least seen as such by some Muslim respondents) because it treats Muslim Americans as "other".

Chapter 5 draws parallels between the current state of public concern about Islam with the mid-twentieth century scrutiny of communists and socialists by Senator Joseph McCarthy and his allies. It suggests that McCarthy's program and some contemporary treatments of US Muslims are both un-American in their failure to live up to the ideals of the country.

The final chapter brings the bulk of the research (conducted between 2009 and 2014) into discussion with the political and social situation in 2016, when the book manuscript was completed. It also suggests a number of policy and civic proposals aimed at increasing cross-cultural understanding.

Besheer Mohamed Senior Researcher Pew Research Center 